Meta

Journal des traducteurs

Translators' Journal

\title{
The Right of Abode Issue: Its Implication on Translation
}

\section{Emily Poon Wai-Yee}

Volume 47, numéro 2, juin 2002

Traduction et terminologie juridiques

URI : https://id.erudit.org/iderudit/008010ar

DOI : https://doi.org/10.7202/008010ar

Aller au sommaire du numéro

Éditeur(s)

Les Presses de l'Université de Montréal

ISSN

0026-0452 (imprimé)

1492-1421 (numérique)

Découvrir la revue

Citer cet article

Poon Wai-Yee, E. (2002). The Right of Abode Issue: Its Implication on

Translation. Meta, 47(2), 211-224. https://doi.org/10.7202/008010ar

\section{Résumé de l'article}

Cet article décrit les limites des stratégies de la traduction juridique en explorant la question du droit de résidence à Hong-Kong, le premier cas auquel a été abordé le rôle de l'interprétation depuis la restitution à la souveraineté de la République populaire de Chine en 1997. Les différentes approches à l'interprétation de la mini-constitution, la Loi Fondamentale, par la cour d'Appel, le Gouvernement de Hong Kong et les Autorités Centrales aussi bien que l'opinion publique sur la question laisseront les traducteurs sans autre choix que de traduire un texte qui porte des termes avec une interprétation aussi littérale que possible afin de ne pas changer le sens du texte original.
Ce document est protégé par la loi sur le droit d'auteur. L'utilisation des services d'Érudit (y compris la reproduction) est assujettie à sa politique d'utilisation que vous pouvez consulter en ligne.

https://apropos.erudit.org/fr/usagers/politique-dutilisation/ 


\title{
The Right of Abode Issue: Its Implication on Translation
}

\author{
EMILY POON WAI-YEE \\ Open University of Hong Kong, Hong Kong
}

\begin{abstract}
RÉSUMÉ
Cet article décrit les limites des stratégies de la traduction juridique en explorant la question du droit de résidence à Hong-Kong, le premier cas auquel a été abordé le rôle de l'interprétation depuis la restitution à la souveraineté de la République populaire de Chine en 1997. Les différentes approches à l'interprétation de la mini-constitution, la Loi Fondamentale, par la cour d'Appel, le Gouvernement de Hong Kong et les Autorités Centrales aussi bien que l'opinion publique sur la question laisseront les traducteurs sans autre choix que de traduire un texte qui porte des termes avec une interprétation aussi littérale que possible afin de ne pas changer le sens du texte original.
\end{abstract}

\begin{abstract}
This paper explores the limitations on legal translation strategy by looking at the right of abode issue in Hong Kong - the very first case in which the role of interpretation was argued since the return of sovereignty to China in 1997. The different approaches to interpreting the mini-constitution, the Basic Law, by the Court of Final Appeal, the Hong Kong Government and the Central Authorities as well as public opinion on the issue will leave translators with no choice but to translate a text that carries terms with open interpretation as literally as possible so as not to affect the substance of the original text.

This paper also discusses the strategy of translating a judgement made by a legal body. Legal bilingualism should enable the general public to understand the law to a greater extent than they previously did. A user-friendly approach to translation will accelerate the assimilation of the common law into the Chinese culture and language.
\end{abstract}

\section{MOTS-CLÉS/KEYWORDS}

Hong Kong, translation of judgements, Chinese culture, abode issue

\section{Background}

The Sino-British negotiations on China's restoration of sovereignty over Hong Kong started in 1982. To accommodate the recovery of sovereignty, and the conflict between the socialist system of Mainland China and the capitalist system of Hong Kong, the negotiations ended with the signing of the Joint Declaration in December 1984, which promised to implement the policy of "one country, two systems," giving Hong Kong a high degree of autonomy. The principles of the Joint Declaration were enshrined in a Basic Law, which was promulgated in April 1990. The establishment of the Hong Kong Special Administrative Region (HKSAR) in 1997 ended the British colonial rule of the past 150 years.

The Basic Law is regarded as the "mini-constitution" of Hong Kong (it is referred to in this way because the HKSAR was established according to the formal Constitution of the People's Republic of China (PRC)), delineating the rules of the government and how the "one country, two systems" policy will be implemented. However, this 
constitution is brief and concise and does not elaborate on all the rules and principles stated therein. Given the nature of this constitution, Wesley-Smith has pointed out that, "The relationship between the Basic Law and the SAR legislation has yet to be clearly worked out. The meaning of the 'one country, two systems' slogan cannot be known without some years of practical operations." (1998: 11)

The "two systems" slogan allows the coexistence of socialism on the Mainland and capitalism in Hong Kong. To maintain Hong Kong's prosperity and stability, its existing system, including the judicial system and the laws, will remain unchanged for another 50 years (see articles 5, 8, 19 and 81 of the Basic Law). However, the high degree of autonomy given to Hong Kong in article 2 is circumscribed by the "one country" formula. Mainland China will play a key role in certain aspects to exercise its control over Hong Kong. One aspect has been correctly noted by M. K. Chan: "While the judiciary is independent of the executive, China has introduced a distinction between adjudication and interpretation, unknown to Hong Kong's existing common law system." (1991: 28) While the Court of Final Appeal (CFA) is vested with the power of final adjudication (see article 82), the interpretation of the Basic Law is divided between the Hong Kong courts and the Standing Committee of the National People's Congress (NPCSC) in Beijing (article 158). It is the division of the power of interpretation that triggers the right of abode argument.

\section{Right of Abode Issue}

The Basic Law, acting as an interface between the two legal systems, received its first challenge on the question of interpretation after the CFA's ruling on the right of abode case, which was handed down on 29 January 1999. The court's ruling conferred the right of abode on children of Hong Kong permanent residents regardless of whether they were illegitimate or born before their parents acquired residency status and it ruled that no exit approval was required from the Mainland. The relevant provisions in the Basic Law were later interpreted by the NPCSC on 26 June in accordance with article 67(4) of the Chinese Constitution and article 158 of the Basic Law at the invitation of the HKSAR government.

The NPCSC's interpretation received innumerable criticisms and comments from many of the legislators, legal experts and scholars in both the Mainland and Hong Kong. Profuse discussions have taken place to investigate the rationale, legality and impacts of the reinterpretation, but little was said about translation, which is an essential component of legal bilingualism. This paper will explore some of the limitations and methods of legal translation based on the right of abode case.

The right of abode case that I am referring to is $\mathrm{Ng} \mathrm{Ka} \mathrm{Ling} \mathrm{and} \mathrm{Ors} v$ Director of Immigration [1999] 1 HKC 291', in which the CFA's decision on 19 January 1999 caused great concern for both the Mainland and the Hong Kong government. In this case, the CFA was able to review the judgements given in the Court of First Instance ${ }^{2}$ and the Court of Appeal ${ }^{3}$.

The provisions in the Basic Law that gave rise to heated debate include articles 24(2)(3) and 22(4). Article 24(2)(3) states that persons of Chinese nationality born outside Hong Kong of a parent or parents covered by articles $24(2)(1)^{4}$ and $(2)^{5}$ also qualify as Hong Kong permanent residents. The definition of article 24(2)(3) is complicated by the stipulation in article 22(4), which states that for entry into the 
HKSAR, people from other parts of China must apply for approval. However, there is no indication in the Basic Law that article 24(2)(3) should be read as being subject to article 22(4).

One of the points of legislation under debate was the Immigration Ordinance (Cap. 115), which was amended by the No. $2^{6}$ and No. $3^{7}$ Ordinances. The No. 2 Ordinance was enacted immediately before the transfer of sovereignty while the No. 3 Ordinance was enacted on 10 July 1997, but both were deemed to come into operation on 1 July 1997. Paragraph 2 of Schedule 1 of the No. 2 Ordinance set out the categories of persons who are permanent residents of the HKSAR. It was stated in paragraph 2(c) that a person of Chinese nationality born outside Hong Kong should have been born to a parent who had acquired the right of abode in Hong Kong at the time of his birth. Paragraph 1(2)(b) of the same Schedule provided that a child, claiming the right of abode through his father but born out of wedlock ${ }^{8}$, did not qualify as a claimant for permanent residency. The No. 3 Ordinance required a claimant to obtain a certificate of entitlement from Hong Kong and a one-way exit permit from the Mainland authorities before he could obtain the right of abode.

In the $\mathrm{Ng}$-CFA case, the CFA had to decide, inter alia, the following issues':

a. whether the No. 3 Ordinance is constitutional on the grounds that article 24(2)(3) is qualified by article 22(4) of the Basic Law and the claimants have to be subject to the approval of the Mainland authorities for entry into Hong Kong.

b. whether the No. 2 Ordinance is constitutional when it includes a wedlock requirement in its definition of the father and child relationship while article 24(3) of the Basic Law is silent on wedlock.

\section{Implication of the Translation Method of the Basic Law}

As the Basic Law is an important document that provides the constitutional basis for the establishment of the HKSAR, translators incline to adhere to the principle of fidelity in producing a parallel text. To have a translation that is as faithful to the original text as possible, many lawyers or legal translators are in favour of the approach of "literal translation." Newmark commented that legal translations have to be flawless, not only referentially but also linguistically, unlike any other type of translation (1993: 16). Cesana held the view that a legal translator's task is to faithfully reproduce the source text, allowing concessions for linguistic divergencies only when absolutely necessary ${ }^{10}$ (Sarcevic, 1997: 91). Others favoured a purpose-oriented approach while agreeing that "accuracy in meaning" is important. Obenaus commented that, "[...] we are all the more unwilling to let go of the notion of equivalence when it comes to legal documents. In our efforts to be precise, to translate every word, to hammer out an equivalent that covers every aspect, we must be careful not to end up saying nothing at all. To be sure, precision and accuracy are essential in legal translation, not in finding equivalents but in achieving the intended function of the translation.” (1995: 249-250). Sarcevic expressed similar views: “[...] the translator should strive to produce a text that is equal in meaning and effect with the other parallel texts [...] This, however, is not the ultimate goal in a receiveroriented approach to legal translation [...] the presumptions of equal meaning and effect are subordinate to the presumption of equal intent. In other words, a reliable translation is one that expresses the intended meaning and leads to the intended results." (1997: 72 and 88) 
To determine whether this mini-constitution should be translated literally, we have to reach an understanding of what the nature of the words used in a constitution is and how we should interpret the constitution. Chase, in his book, The Tyranny of Words, described the language of a constitution as highly abstract or what he called the "weasel words in the jargon of lawyers." (Brighan, 1978: 25) Therefore, the meaning of the words is determined by the particular context at a particular time or relies on the subjective interpretation of a judge. Fiss, who studied the objectivity of law, pointed out that the nihilist rejected the possibility of objectivity in constitutional text since "the text is capable of any number of possible meanings, and thus it is impossible to speak of one interpretation as true and the other false." (1994: 436) As a result of the flexibility of words, different models for constitutional interpretation emerged. One of the most common approaches suggested is originalism or textualism, which gives priority to the original meaning of the text or the original intention of the framers of the constitution.

In $\mathrm{Ng}$ 's case, the five applicants, who were selected as test cases for judicial review, were rejected entry into Hong Kong by the Immigration Department, which was acting in accordance with the No. 2 and 3 Ordinances. The decisions made by different levels of the courts are as follows:

a. The Court of First Instance's decision in October 1997 ([1997] 3 HKC 64: see appendix I): the judge dismissed all the applications with the exception of one case, where he declared that the wedlock requirement in the definition of the father and child relationship as stated in the No. 2 Ordinance was unconstitutional.

b. The Court of Appeal's decision in April 1998 ([1998] 1 HKC 617: see appendix II): the judges unanimously upheld the constitutionality of the Certificate of Entitlement Scheme as embodied in the No. 3 Ordinance, but held that the wedlock requirement in the No. 2 Ordinance was unconstitutional.

c. The Court of Final Appeal's decision in January 1999 ([1999] 1 HKC 291: see appendix III): The No. 3 Ordinance was unconstitutional in requiring permanent residents of the HKSAR residing on the Mainland to hold a one-way permit before they could enjoy the right of abode. The No. 2 Ordinance was unconstitutional in excluding, in relation to the father, a child born out of wedlock.

The NPCSC's interpretation of the Basic Law provisions differed from the CFA ruling in the following ways:

a. Article 24(2)(3) will mean that only mainlanders born after one of the parents has become a permanent resident of Hong Kong can enjoy the right of abode. (But the NPCSC accepts children born in and out of wedlock, as ruled by the CFA.)

b. Article 22(4) will mean that mainlanders, including Hong Kong permanent residents' children who are eligible to claim the right of abode under article 24(2)(3), must seek an exit permit from Mainland China before they can enter Hong Kong.

From the above observation, translators of the constitution are tempted to make a literal translation which emphasizes as much closeness to the original as possible due to the reasons below:

a. The provisions in dispute are ambiguous in the following ways:

(i) In article 22(4), "people from other parts of China" can include or exclude people with the right of abode in Hong Kong. This means article (24)(2)(3) may or may not be read as being subject to article 22(4). 
(ii) In article 24(2)(3), there is no indication whether "birth" (i.e. a child should be born after one parent has become a permanent resident) is a prerequisite for obtaining the right of abode. Moreover, it does not mention whether "status" (i.e. if the provision is only referring to legitimate children or if it includes also illegitimate and adopted children ${ }^{11}$ ) is a prerequisite.

b. In $\mathrm{Ng}^{\prime}$ 's case, different parties interpreted the Basic Law in different ways:

(i) Andrew Li (from the CFA) followed a generous and purposive approach in the interpretation of the Basic Law: "The adoption of a purposive approach is necessary because a constitution states general principles and expresses purposes without condescending to particularity and definition of terms [...] So in ascertaining the true meaning of the instrument, the courts must consider the purpose of the instrument and its relevant provisions as well as the language of its text in the light of the context. [...] The purpose of a particular provision may be ascertainable from its nature or other provisions of the Basic Law or relevant extrinsic materials including the Joint Declaration. As to the language of its text, the courts must avoid a literal, technical, narrow or rigid approach. They must consider the context. The context of a particular provision is to be found in the Basic Law itself as well as relevant extrinsic materials including the Joint Declaration." ${ }^{2}$

(ii) Mortimer (from the Court of Appeal) also favoured a similar approach which can give individuals the full measure of the fundamental rights and freedoms referred to. He agreed with Lord Wilberforce's comments that respect must be paid to the language which has been used and to the traditions and usages which have given meaning to that language. ${ }^{13}$ To protect people's fundamental rights and freedoms, he further said, "That where legislation has been passed within the general provisions of the Basic Law to provide specific, detailed and certain rules, I would give effect to the legislation provided that the legislation is clearly within the provisions of the Basic Law and does not deprive a person of his constitutional rights or so restrict them as to amount to a deprivation." 14

(iii) Geoffrey Ma SC (Counsel for the Immigration Department) submitted that the Basic Law should be construed in line with the laws of Mainland China. Adopting a purposive approach, he said that article 24 must be construed in the light of article 22(4) since it has always been the law of the PRC, which requires approval for exits from the Mainland. Hence, article 24 should not be construed in such a way as to encourage a breach of the PRC immigration laws. ${ }^{15}$ He further submitted that the Basic Law should be construed bearing in mind its international dimension. Any subsequent agreement to an international treaty regarding its interpretation or application must be taken into account when construing it. He said paragraph 1(2)(b) in Schedule 1 (which defined the relationship of father and son) was enacted by the legislature to fill the lacuna of article 24(2)(3) to reflect public policy and the policy of the State Council, which is the executive body of the highest organ of state power in the PRC. ${ }^{16}$

(iv) Denis Chang SC (Counsel for the appellants) argued that it was unconstitutional to use ordinary legislation to claw back fundamental rights contained in a constitution on the basis that the constitution had imperfectly expressed the intention of the drafters. ${ }^{17}$

(v) Tung Chee Hwa (Chief Executive of HKSAR) in his report to the State Council on 20 May 1999 stated the reasons why the Government had to invite the NPCSC to interpret articles 22(4) and 24(2)(3). The construction of the Basic Law seems to rely on the overall interests of Hong Kong: "The statistical surveys conducted by the HKSAR Government (HKSARG) show that under the CFA's rulings, the number of Mainland people who are eligible for the right of abode in Hong Kong 
would be increased by at least 1.67 million. [...] The assessment of the HKSARG is that the admission of these additional people would create enormous pressure on Hong Kong. ..... This would trigger social problems and lead to consequences which would have a serious and adverse effect on the stability and prosperity of Hong Kong. [...] The CFA's interpretation of the relevant provisions of the Basic Law is different from the HKSARG's understanding of the working, purpose and legislative intent of these provisions. Queries and arguments as to whether the CFA's interpretation is in line with the Basic Law have been raised in the community. Public opinion is overwhelmingly in favour of an early resolution of this issue." ${ }^{18}$ (p. 3-4)

(vi) The NPCSC, when announcing its interpretation on 26 June 1999, stated that the legislative intent of article 24(2)(3) was reflected in the Opinions of the Preparatory Committee adopted by the NPC on 10 August 1996. It interpreted article 22(4) based on the existing immigration and emigration systems that have long been implemented in the Mainland and in Hong Kong. ${ }^{19}$

From the above quotations, one may notice that most parties do not depart from the traditional mode of interpretation, i.e. to ascertain the legislative intent from the ordinary meaning of the words used as well as from any relevant extrinsic documents.

However, the interpretation is complicated by the hybrid nature of the Basic Law-a product coming from the struggle between the common law system and the socialist legal system. As Ghai put it, "A fundamental question to be resolved is the provenance of the Basic Law: whether it is to be treated as Chinese law requiring the application of Chinese rules of interpretation or as an instrument embedded in the common law given that the underlying law of the HKSAR will be the common law." (1999, p. 191) J. M. M. Chan held the view that "sovereignty" should not be a consideration: "[...] any emphasis on sovereignty in the interpretation process is likely to be misconceived. [...] the meaning of the Basic Law should first be ascertained within the four corners of the Basic Law and be construed in light of the Joint Declaration and the Preamble and the General Principles set out in Chapter 1 of the Basic Law. Sovereignty, save in very exceptional circumstances, is an irrelevant consideration." (1998: 8)

If a translator can foresee how a text will be interpreted, it will be easier for him to produce a text that is functionally adequate. But how a text is interpreted depends largely on the legal system in which it lies. A legal translator sometimes has to look beyond the language of a text. It has been correctly pointed out by Beyer and Conradse that, "[...] legal translation is extremely difficult; one is translating not only the words on the page but the underlying legal system as well." (1995: 145-146)

Bearing in mind the NPCSC's interpretation of article 22(4), “中國其他地區的人20 進入香港特別行政區須辦理批准手續” can be translated ${ }^{21}$ in a more precise way as “For entry into the HKSAR, any ${ }^{22}$ people from other regions of China must apply for approval." ${ }^{23}$ If a translator is unaware of which policy he should follow, very often he can only produce a literal translation (in this case here, most probably without the addition of the word "any"). Ambiguity or imprecision in a literal translation will create tension in communication and arguments as to the meaning of a given expression will arise. As stated by Smith, "Linguistic difficulties often arise when two legal cultures clash during translation [...] The root of these problems lies in their varying legal histories, cultures, and systems." (1995: 179) The civilian tradition of the Main- 
land is quite different from the common law tradition. As the CFA judges consider the Basic Law from a human rights standpoint, they are more inclined to adopt a broad interpretation (saying that articles 24(2)(3) and 22(4) do not make reference to each other and it is invalid to define the word "people" to include those with right of abode in Hong Kong) so as not to undermine human rights.

What complicated the matter is that Hong Kong's common law system is not only influenced by the Mainland law system, but also the collective interests of the public. This lays down a benchmark that the interpretation of the Basic Law will take Hong Kong's practical needs into consideration. As the public was afraid that the CFA ruling would result in an influx of 1.67 million migrants, most people were dissatisfied with the court ruling. ${ }^{24}$ Lau commented that the public has changed its views on law in a post-colonial society, "In contrast to the common law perspective, law is treated by Hong Kong people primarily as a means to other ends, and hence its intrinsic value is limited. [...] the public looks at substantive justice as defined by dominant social values and collective needs, not the procedural justice that is frequently held by the legal community to be the pride of common law." (1999: 11)

We can conclude from the above study that legal texts, unlike other text genres, are often affected by unstable non-linguistic variants. A translator can only ascertain the "intended meaning" or "intended function" of a text from the wordings used and produce a semantically and syntactically literal translation so as not to affect the substance of the source text. Its accuracy sometimes depends not on how a translator translates it, but on how much detail is contained in a legal document and how the content should be interpreted.

\section{Translation of Judgements}

In 1987, the passing of the Official Languages (Amendment) Ordinance and the Interpretation and General Clauses (Amendment) Ordinance paved the way for legal bilingualism in Hong Kong. One of the objectives of legal bilingualism, as the Law Drafting Division of the Department of Justice has noted, is "to root the common law in the Chinese language." (1999: 39) The source of our common law system includes both statutory law and case law. As of the present time, all the statutes are bilingual. However, no concerted efforts were made by the Government to translate case law, which is a collection of authoritative judgements whereby the lower courts are obliged to follow the decisions of the higher courts.

Many legal philosophers and scholars have given their opinions on the advantages of a bilingual legal system. One of the consequences that will benefit Hongkongers is what Zhao has said, "After 1997, the English language will not lose its official status. Use of the Chinese language, however, will enable Hong Kong residents to receive legal advice, obtain information about legislation and attend court hearings in their own language." (1997: 303) However, Zhao reminded us that the task of implementing Chinese as a legal language was difficult since legal translation also involved the translation of legal concepts: "Legal concepts are difficult to translate from one language to another because they are identified and expressed in the context of the accompanying legal system, and therefore, bear their own particular meaning. [...] The strict requirement of accuracy and precision in legal translation makes the task even more difficult." (1997: 311) 
With discernible progress made in bilingual legislation, a collection of Chinese legislative terms is readily available for the judicial process and court records. However, the use of the Chinese legal terms is still rare in the higher courts as the cases there always involve complicated points of law. Does this imply that the so-called Chinese equivalents are inadequate to express the full meaning of the common law concepts? Legal practitioners still do not have enough confidence to use the Chinese terms in judicial reasoning because they worry that their common law meanings will not be fully understood. And if a layman just looks at a translation of the legal terms (e.g. from the court records), it is conceivable that he will not understand the legal concepts behind them.

The Law Drafting Division has suggested using "adequacy" and "acceptability" as the criteria for selecting a Chinese term. "Adequacy" means that a Chinese term can carry the meaning of its English equivalent. "Acceptability" means the Chinese translation complies with the grammatical and usage rules of the Chinese language and that it is comprehensible. However, one will doubt whether the Chinese language that we are using can easily achieve "adequacy," as our language is not accustomed to representing the common law which is customarily based in English law. To solve the problem, we can either coin new words or plant new meanings with the existing Chinese vocabulary to match the English legal terms. Therefore, we can only expect a closeness in meaning, but not an identical meaning and that is why both Zhao (1997: 302) and Sin (1989: 513-514; 1992: 96-98) commented that the Chinese version could only acquire its meaning through English. This means that the Chinese version cannot be understood independently of the English version.

However, if the Chinese version could not be understood independently and the riches of common law are still restricted for legal practitioners, what is the point of having a bilingual legal system? If we believe that allowing the common law concepts to take root in the Chinese language or culture is the very aim of legal bilingualism, we have to strive for a solution so that the Chinese version is not a mere translation, but a user-friendly guide so that even a layman can grasp the basic knowledge of law and make use of this knowledge to defend himself in the courts. Perhaps, we can start with judgements, which are not as formal as legislation and are easier to understand.

The CFA judgement was translated ${ }^{25}$ by the Judiciary since it has important reference value. To find out whether the message conveyed can be understood in the translation, we need to examine how the translator coped with the legal terms, which as Brown said are "the building blocks of a legal document." (1995: 69) However, they are also the stumbling block to the comprehension of the text if they are not dealt with adequately. The translator of this judgement gave a literal translation to the legal terms. The two examples that I would like to cite here are:

\section{Example 1:}

"Secondly, if there is unlawful delay by the Director (of Immigration) in coming to a decision whether to accept or reject an application, the person concerned, although in the Mainland, can invoke public law remedies in our courts." (p. 63)

“其次, 如果入境處處長不合法地拖延作出接納或拒絕申請的決定, 有關申

請人雖然身處內地, 仍可向特區法院要求作出公法上的補救。” (p. 52) 


\begin{abstract}
Example 2:
"Mr Dykes SC who argued this issue (referring to the Provisional Legislative Council issue) for the applicants submits that the Provisional Legislative Council was not the legislature provided for in the Basic Law and was not a legally constitutional body. Any legislation passed by it would only be valid if it satisfied the common law doctrine of necessity." (p. 78-79)
\end{abstract}

“資深大律師戴啓思先生爲申請人爭辯這個問題時提出, 臨時立法會並不是

《基本法》內所訂明的立法機關，並不是一個合法組成的機構。任何經“臨

立會”通過的法例必先符合普通法的“必需原則”方爲有效。” (p. 52)

“Public law remedies" and “doctrine of necessity” were translated as “公法上的 補救” and “必需原則” respectively. The expression “公法上的補救” can achieve “adequacy” and "acceptability" as proposed by the Law Drafting Division. However, the expression “必需原則” looks a bit strange to Chinese readers since “必需” is usually used to modify a verb instead of a noun. Even if “公法上的補救” and “必需原則” are semantically and syntactically equivalent to the original, they are still not comprehensible to monolingual users since legal terms can acquire their meaning only in the context of a particular legal system. (Cao, 1997: 664) To solve the problem, a footnote can be added to explain the legal concept behind them. I suggest adding the following footnotes to the original text:

Public law remedies: They are means governed by public law to recover rights or to obtain redress through judicial process. They include (a) certiorari (to quash a decision), (b) prohibition (to prevent a decision from being made), (c) mandamus (to compel the carrying out of duty according to law), (d) declaration (to declare by the court the position in law based on given facts) and (e) damages (to compensate a loss (rarely used)).

Doctrine of necessity: It is a principle of law that accepts a course of action as necessary under special circumstances. In the absence of a "through train" for the last colonial legislature, the Preparatory Committee, using the "doctrine of necessity," established the Provisional Legislative Council in early 1996 to fill the "legislative vacuum" (i.e. to perform the essential functions of a legislature) in the period from 1 July 1997 until the formation of the first Legislative Council in mid 1998. (Chen, 1997)

The writing of these footnotes can be done by the Editorial Board of the law report on a separate sheet to be attached to the judgement for public reference ${ }^{26}$. The job of a translator is to translate the footnotes. The insertion of footnotes in legal documents is not something out of the ordinary. Brown (1995) told us his experience of working as a translator for a Soviet republic law firm where Soviet laws were translated for potential Western investors' reference. He found it hard to produce a close-to-the-original rendition that could be easily read and understood by the target readers, free of footnotes. (p. 68) Footnotes were added in the translations by him to suggest how to improve the wordings or structure of a point of legislation and to tell the readers the translation methods he employed.

This right of abode case was first heard by Mr. Justice Keith in the Court of First Instance in September 1997. The judge in his judgement added as many as 40 footnotes $^{27}$, which can be seen in the law report Hong Kong Cases. ${ }^{28}$ ([1997] 3 HKC 64) This proves that footnotes are allowed in judgements. Keith, in the footnotes, provided us with the law background of some of the important sections. For example, in 
footnote 3, we are told that the exit permit requirement that has been carried out for decades is based on article 17 of the "Law on the Control of the Exit and Entry of Citizens" and article 3 of the "Interim Measures for the Administration of Chinese Citizens on Passage to and from the Regions of Hong Kong or Macao for Personal Affairs." With the help of the footnotes, readers will find it much easier to understand the reasoning given by the judge. The judge also made use of the footnotes to tell us the source of some sections that we can refer to. For example, in footnote 13, we learn that the method by which the Immigration Department deals with an application has been specified in Gazette Notice (Extraordinary) No. 21 of 1997. It is interesting to note that the judge also gave us the source of an idiom quoted by a counsel in his submission. ${ }^{29}$

Writing footnotes in judgements to educate the public is one important step to root the common law in the Chinese culture. When Hongkongers are accustomed to using Chinese in the legal context, Chinese will be more sophisticated as a legal language, like its English counterpart.

\section{Conclusion}

This paper addresses some of the difficulties of legal translation. Despite the fact that translators may sometimes have their hands tied by the linguistic and non-linguistic problems of the two languages and legal cultures, they have to try their best to give a faithful translation in the target language. This paper suggests a method of translating judgements. In developing Chinese into a legal language, it is insufficient to give only a literal translation to the legal terms, readers must be provided with the linked legal concepts. A user-friendly piece of translation can enable the common law to be more easily assimilated into the Chinese culture.

\section{NOTES}

1. There are other related right of abode cases on separate issues, such as the issue on "adopted children."

2. See [1997] 3 HKC 64.

3. See [1998] 1 HKC 617.

4. Chinese citizens born in Hong Kong before or after the establishment of the HKSAR.

5. Chinese citizens who have ordinarily resided in Hong Kong for a continuous period of not less than 7 years before or after the establishment of the HKSAR.

6. See the Immigration (Amendment) (No. 2) Ordinance 1997.

7. See the Immigration (Amendment) (No. 3) Ordinance 1997.

8. This was different from the relationship of a mother and child as described in paragraph 1(2)(a) of Schedule 1, which did not exclude a child born out of wedlock.

9. Only two main issues are listed here as they are related to the translation problems to be discussed in this Paper. Other issues decided by the CFA in this case include seeking interpretation from the NPCSC and the legality of the Provisional Legislative Council.

10. In a debate on the translation of the Swiss Civil Code in the early 1900s, G. Cesana, an attorney in Zurich (later Lugano and Milan) severely criticized the approach of "free translation."

11. See Xie Xiaoyi v Director of Immigration ([1999] 2 HKLRD 505: see appendix IV). In this case, the judge held that the relationship of parent and child in article $24(2)(3)$ should not be limited to the relationship that arose as a result of birth, but should also include the legal relationship between a child and his adoptive parents. However, the ruling has recently been overturned by the Court of Appeal ([2000] 2 HKLRD 161: see appendix V).

12. See [1999] 1 HKC 291 at 325-326.

13. See Minister of Home Affairs v Fisher [1980] AC 319 at 328. 
14. See [1998] 1 HKC 617 at 662.

15. See [1998] $1 \mathrm{HKC} 617$ at 637.

16. See [1998] 1 HKC 617 at 646.

17. See [1998] 1 HKC 617 at 647.

18. Another reason stated is that the issue concerned the relationship between the Central Authorities and the HKSAR.

19. See the "Interpretation by the NPCSC of articles 22(4) and 24(2)(3) of the Basic Law of the HKSAR of the PRC" made on 26 June 1999 and its explanatory note given by X. Y. Qiao, the Deputy Secretary of the NPCSC's Legislative Affairs Commission, on 22 June 1999.

20. I think the character “人” is too vague to convey exactly what the NPCSC means. This can be replaced by “任何人士.”

21. The Basic Law was drafted in Chinese. The Chinese version will prevail if there is any inconsistency with the English translation.

22. "Any" is added here to also include those mainlanders who are eligible to claim right of abode under article 24 .

23. The original translation "people from other parts of China" is ambiguous. Both "people" and "parts" can be open to interpretation. Please also see L. Y. Cha's 查良鏞 comments on the right of abode crisis published in the Oriental Daily News on 18 May 1999.

24. This is evident from the result of an opinion poll commissioned by the Chinese University of Hong Kong which found that $78.5 \%$ considered the CFA ruling wrong as it would increase the social and economic burden on Hong Kong. See S. K. Lau's commentary on common people's law published in South China Morning Post on 27 June 1999.

25. See $\mathrm{Ng} \mathrm{Ka}$ Ling and Ors $v$ Director of Immigration (unreported) FACV Nos 14-16 of 1998 for the original text and its translation.

26. These footnotes cannot be cited as authority as they are not the words of a judge as contained in a judgement.

27. These footnotes are authoritative as they are part of the judgement mainly to provide exposition of some of the legal concepts.

28. But the Hong Kong Law Reports \& Digest, when reporting the case, did not report those footnotes. See [1997] HKLRD 1081.

29. See footnote 29 at [1997] 3 HKC 64 . The idiom "the dog which did not bark in the night" originated from the Memoirs of Sherlock Holmes.

\section{APPENDIX}

I. [1997] 3 HKC 64

Prior to the 1 July 1997 handover, the entry of mainlanders into Hong Kong was regulated by the exit permit policy of the People's Republic of China (PRC). Article 24(2)(3) of the Basic Law, which took effect on the date of the handover, gives Mainland children who are born of permanent residents of Hong Kong the right of abode in Hong Kong. Many of these children, who hid themselves in Hong Kong before 1 July 1997 approached the Immigration Department after that date and, pursuant to article 24(2)(3), applied for the recognition of their status as permanent residents of Hong Kong. However, they were all rejected by the Immigration Department, which acted according to the No. 2 and No. 3 Ordinances. These two ordinances were passed by the Provisional Legislative Council to amend the Immigration Ordinance (Cap. 115) so as to make qualifications to the application of right of abode in Hong Kong and they were deemed to come into operation on 1 July 1997, though the No. 3 Ordinance was enacted on 10 July 1997. Many of these children sought assistance from the Legal Aid Department to challenge the legality of the Immigration Department's decisions. Four test cases (totaling 5 applicants: Cheung Lai Wah, Ng Ka Ling, Ng Tan Tan, Tsui Kuen Nang and Yeung Ni Ni) were selected by the Legal Aid Department for judicial review. The cases were consolidated and heard before the same judge in the Court of First Instance in September and October 1997 to decide the correct interpretation of the captioned provisions of the Basic Law as well as the constitutionality of the two Immigration Ordinances. 
On 9 October 1997, when passing sentence the judge of the Court of the First Instance dismissed nearly all the applications, four cases in total, and held that, inter alia, the No. 3 Ordinance was constitutional and article 24 of the Basic Law should be qualified by article 22(4) (i.e. entry into Hong Kong should be subject to the exit policy of the Mainland authorities). However, the judge ruled that in the case of Cheung Lai Wah, the wedlock requirement in the relationship between father and child in the No. 2 Ordinance was unconstitutional.

II. [1998] 1 HKC 617

The Director of Immigration appealed against the judge's ruling on the No. 2 Ordinance with regard to Cheung's case while the applicants appealed against the dismissal of the other applications.

The case was heard in March and April 1998 in the Court of Appeal, which dealt with the following issues:

a. the constitutionality of the No. 3 Ordinance;

b. the validity of the retrospective provisions in the No. 3 Ordinance; and

c. the validity of the legitimacy or wedlock requirement in the relationship between father and child in the No. 2 Ordinance.

On 2 April 1998, the court unanimously upheld the constitutionality of the Certificate of Entitlement Scheme as provided in the No. 3 Ordinance and by a majority held that the retrospective provisions in this Ordinance were valid and did not affect the applicants who came to Hong Kong before 1 July 1997. However, the court unanimously upheld that the definition of the relationship between father and son in the No. 2 Ordinance was unconstitutional.

III [1999] 1 HKC 291

Appeals and cross-appeals by the Director of Immigration and the applicants took place in the CFA in January 1999. In submission, the Director of Immigration questioned the adjudicating power of the Court, contending that as the issue under contention concerned the relationship between the Central Authorities and the HKSAR, the Court should refer article 22 to the NPCSC for interpretation pursuant to article 158(4) of the Basic Law.

Other issues that the Court had to decide included:

a. how the Basic Law should be interpreted;

b. whether the Court should seek interpretation from the NPCSC;

c. whether the Certificate of Entitlement Scheme as introduced by the No. 3 Ordinance was constitutional;

d. whether the retrospective provision in the No. 3 Ordinance was constitutional (If the retrospective provision was constitutional, any mainlanders who had arrived in Hong Kong before the enactment of the No. 3 Ordinance on 10 July 1997 were not eligible to the right of abode as they could not have held the Certificate of Entitlement before 10 July 1997.);

e. whether the wedlock requirement in the definition of the parent and child as introduced by the No. 2 Ordinance was constitutional; and,

f. whether the Provisional Legislative Council was a legally constituted body (Counsel for the applicants argued that it was not the legislature provided in the Basic Law and thus it was not legal and, therefore, the retrospective provision in the No. 3 Ordinance accordingly was invalid.).

The CFA gave its decision on 29 January 1999. Two of the rulings that gave rise to criticism from Beijing and heated debate from the society of Hong Kong were:

a. The CFA ruled that article 22(4) did not apply to those mainlanders with the right of abode in Hong Kong. It granted right of abode to mainland children of Hong Kong residents regardless of whether their parents were married or whether a parent was a permanent resident at the time of birth. Both the No. 2 and No. 3 Ordinances were unconstitutional. 
b. The CFA held that the NPC and its SC were bound by the Basic Law and that Hong Kong courts had the jurisdiction to examine their legislative acts for consistency with the Basic Law. The Court ruled that it had jurisdiction over the case since the definition of permanent residency was a matter for Hong Kong.

There was a warning that the court ruling was a challenge to the NPC and would lead to constitutional crisis. The Hong Kong Government later requested clarification from the CFA in order to avoid any constitutional crisis. On 26 February, 1999, the CFA took the unprecedented step of making a statement to declare that the Court's ruling did not question the authority of the NPCSC which could make an interpretation under article 158 which would subsequently have to be followed by the Hong Kong courts and the Court could not question acts of the NPC or its SC which were in accordance with the Basic Law.

To stop an influx of mainland migrants caused by the CFA's ruling, the Government later sought interpretation from the NPC to define articles 24(2)(3) and 22(4) of the Basic Law.

IV [1999] 2 HKLRD 505

The 3 applicants were Chinese nationals born in the Mainland. They were adopted according to the Mainland laws and at least one of their parents was a permanent Hong Kong resident at the time of their birth. They claimed for permanent residency under article 24(2)(3) of the Basic Law. The Director of Immigration turned down their applications. One of the reasons was that the adoption had not been a Hong Kong adoption as required by paragraph $1(2)(c)$ of the Immigration Ordinance.

The applicants applied for judicial review of the decision. The judge finally conferred the right of abode to the applicants on the grounds that paragraph 1(2)(c) imposed a further condition for obtaining right of abode in Hong Kong which was not in article 24. The judge also declared that article 24(2)(3) should not be construed in a way to encourage the splitting of families and the effect of a Mainland adoption was the same as the effect of a Hong Kong adoption.

V [2000] 2 HKLRD 161

This was an appeal made by the Director of Immigration. The main issue under appeal was whether article 24(2)(3) also conferred the right of abode to Mainland adopted children of Hong Kong permanent residents. Article 24(2)(3) gave right of abode to "persons of Chinese nationality born of Hong Kong permanent residents listed in categories (1) and (2)." The judge held that the words "born of" were very clear in that they referred to a relationship created through "natural birth," but not a relationship derived from adoption or step-parentage. The judge also concluded that paragraph $1(2)(c)$ of the Immigration Ordinance was not in any way in conflict with article $24(2)(3)$ as adopted children were not a category of persons accepted by article 24(2)(3). The judge allowed the appeal.

\section{REFERENCES}

Brigham, J. (1978): Constitutional language. Westport: Greenwood Press.

Brown, C. E. (1995): "Riding the waves of fortune: Translating legislation of the successor Soviet republics.” In M. MoRris (Vol. Ed.). American Translators Association scholarly monograph series: Vol. 8. Translation and the law (pp. 67-83). Amsterdam John Benjamins Publishing Company.

CAO, D. (1997): “Consideration in translating English/Chinese contracts." Meta, XLII, 4, 661-669.

Chan, J. M. M. (1998): Principles of interpretation of the Basic Law: A preliminary enquiry. (Law Working Paper Series Paper No. 19). Hong Kong: The University of Hong Kong, Faculty of Law.

Chan, M. K., \& Clark, D. J. (Eds.). (1991): The Hong Kong Basic Law. Hong Kong: Hong Kong University Press. 
Chen, A. H. Y. (1997): “The provisional legislative council of the SAR.” Hong Kong_Law Journal, 27, 1-14.

Clark, D., \& McCoy, G. (1993): Hong Kong administrative law (3rd ed.). Hong Kong: Butterworths.

Fiss, O. M. (1994): “Objectivity and interpretation.” In J. L. Coleman \& A. Sebok (Eds.), Constitutional law and its interpretation (pp. 433-457). New York: Garland Publishing.

GhaI, Y. (1999): Hong Kong's new constitutional order (2nd ed.). Hong Kong: Hong Kong University Press.

LAu, S. K. (1999, June): “Common people's law.” South China Morning Post, pp. 11.

Law Drafting Division, Department of Justice. (1999, February): "The common law and the Chinese language." Hong Kong Lawyer, 39-42.

Newmark, P. (1993): Paragraphs on translation. Clevedon: Multilingual Matters Ltd.

NPCSC (1999, June): The interpretation by the NPCSC of articles 22(4) and 24(2)(3) of the Basic Law of the HKSAR of the PRC. Interpretation announced at the 10th session of the NPCSC, Beijing, PRC.

Obenaus, G. (1995): “The legal translator as information broker.” In M. Morris (Vol Ed.). American Translators Association scholarly monograph series: Vol. 8. Translation and the law (pp. 247-259). Amsterdam: John Benjamins Publishing Company.

Qiao, X. Y. (1999, June): Explanatory note on the interpretation by NPCSC of articles 22(4) and 24(2)(3) of the Basic Law of the HKSAR of PRC. Explanatory note announced at the 10th session of the NPCSC, Beijing, PRC.

SARCEviC, S. (1997): New approach to legal translation. The Hague: Kluwer Law International.

Sin, K. K. (1989): "Meaning, translation and bilingual legislation." Proceedings of the First Conference of the International Institute of Comparative Linguistic Law, Montreal, Canada. 509-515.

Sin, K. K. (1992): “The translatability of law.” In T. H. T. Lee (Ed.), Research on Chinese linguistics in Hong Kong (pp. 87-101). Hong Kong: The Linguistic Society of Hong Kong.

Tung, C. H. (1999): Report on seeking assistance from the Central People's Government in solving problems encountered in the implementation of the Basic Law of the Hong Kong Special Administrative Region of the People's Republic of China. Hong Kong: Hong Kong Government.

Wesley-Smith, P. (1998): An Introduction to the Hong Kong Legal System (3rd ed.). Hong Kong: Oxford University Press.

Zнао, Y. (1997): "Hong Kong: the journey to a bilingual legal system." 19 Loyola of Los Angeles International and Comparative Law Journal, 19, 293-313.

查良鏞。”不必改, 不可改, 改不成”。(1999 年 5 月 18 日)。東方日報, A2 頁。 